Komunida: Media Komunikasi dan Dakwah

Volume 09 Nomor 02 (2019) 269-281

http://ejurnal.stainparepare.ac.id/index.php/komunida

ISSN 2088-0669; E ISSN 26143704

\title{
Bimbingan Karir Anak Berbasis Kearifan Lokal Bugis
}

\author{
Adnan Achiruddin Saleh \\ IAIN Parepare \\ e-mail: adnanachiruddinsaleh@iainpare.ac.id
}

\begin{abstract}
Abstrak
Kearifan lokal Bugis adalah nilai kebaikan yang menjadi kesepakatan dan dijalankan secara bersama bagi masyarakat Bugis, yang dikenal dengan istilah pappaseng. Salah satu pappaseng dalam lingkup pengasuhan anak tersebut adalah palettu alenu riolo tejjokanu, menjadi penting untuk disampaikan secara terbuka dengan pertimbangan bahwa menjadi pengetahuan dan penerapan bagi anak sendiri dan orang lain serta wacana diskusi bagi akademisi dalam pengujian kaidah ilmiah dan peluang dalam integrasi keilmuan. Pappaseng ini secara terbuka bisa menjadi materi dalam bimbingan karir baik bagi orang tua maupun kalangan professional yang bergerak di bidang pengasuhan anak. Penerapan pada bimbingan karir anak tersebut bisa dalam tahapan awal dalam memetakan kemampuan anak dan kesesuaiannya dengan pekerjaan. Palette alenu riolo tejjokanu bisa diterapkan pada bimbingan karir anak melalui imajinasi karir anak, drama karir, chech list behavior anak, dan diskusi terbuka anak.
\end{abstract}

Kata Kunci: Bimbingan, Karir, Kearifan, Bugis

\begin{abstract}
Local wisdom of Bugis is the value of goodness which is agreed upon and carried out for the Bugis community, known as pappaseng. One of the pappaseng in the scope of childcare is the palettu alenu riolo tejjokanu, it is important to be conveyed openly with the consideration that it becomes knowledge and application for children themselves and others and also discussion discourse for academics in testing scientific principles and opportunities in scientific integration. This pappaseng can openly become material in career guidance for both parents and professionals engaged in childcare. The implementation of the child's career guidance can be in the initial stages in mapping the child's abilities and compatibility with the job. Palettu alenu riolo tejjokanu can be applied to children's career guidance through children's career imaginations, career plays, chindren's chech list behavior, and children's open discussions.
\end{abstract}

Keywords: Guidance, Career, Wisdom, Bugis 


\section{PENDAHULUAN}

Wacana penguatan kearifan lokal menjadi isu yang menarik dalam beragam konteks. Indonesia sebagai salah Negara terbesar memiliki warisan kebudayaan, memiliki peluang yang cukup dalam memindahkan unsur-unsur kebudayaan pada lintas generasi. Banyak kearifan lokal yang patut digali dan dikembangkan karena bangsa ini sangat kaya dengan kearifan lokal yang memiliki nilai tinggi.

Kearifan lokal sudah mulai terkikis. Salah satu yang menyebabkan terkikis dan sulit untuk dikembangkannya kembali kearifan lokal di tanah Indonesia adalah karena ketakutan atau ketaatan dogmatis individu masyarakat Indonesia pada ajaran agama formalnya (Agung, 2012:203). Bagi masyarakat Indonesia yang mayoritas beragama Islam, budaya terlepas dari agama dan agama bukanlah produk dari kebudayaan. Tentu saja hal ini tidak sepenuhnya benar, kerena apabila manusia religius menyakini mereka diciptakan oleh Tuhan, maka Tuhanlah yang menciptakan budaya karena manusia adalah ciptaan Tuhan. Bagi orang tua di Suku Bugis juga terkesan menyembunyikan kearifan lokal tersebut karena dianggap sesuatu yang sakral dan harus dirahasikan. Pada beberapa kearifan lokal tertentu dibutuhkan ritual khusus dalam proses penyampaiannya. Suku Bugis adalah masyarakat Bugis yang mendiami wilayah yang tersebar di beberapa kabupaten di Sulawesi Selatan, termasuk diantaranya adalah Kabupaten Bone, Wajo, Soppeng, Sinjai, Sidenreng Rappang, Pinrang, Maros.

Kearifan lokal dalam Bugis bisa dipahami sebagai Pappaseng. Pappaseng yang dalam masyarakat Bugis dikonstruksi sebagai pesan yang sakral karena merupakan wasiat orang tua atau orang bijak di masa lalu. Wasiat ini berperan penting dalam menjaga struktur kearifan lokal masyarak Bugis hingga saat ini.

Mendiskusikan kearifan lokal menjadi penting untuk dikembangkan agar membangkitkan kembali semangat mempelajari kearifan lokal Bugis. Kita memerlukan sebuah paradigma baru dalam membaca kearifan lokal dengan perspektif yang berbeda. Hal ini dimaksudkan agar dapat membuka tabir dan menyingkap tirai-tirai keluhuran nilai budaya Bugis sehingga tercipta kesadaran bersama akan pengetahuan kearifan lokal tersebut. Ini akan membuka peluang 
bahwa kearifan lokal tersebut tidak semata menjadi dogma yang bebas dari diskusi.

Nilai kearifan lokal Bugis akan memiliki makna apabila tetap menjadi rujukan dalam mengatasi setiap dinamika kehidupan sosial, terlebih lagi dalam menyikapi berbagai perbedaan yang rentan menimbulkan konflik. Keberadaan nilai kearifan lokal justru akan diuji ditengah-tengah kehidupan sosial yang dinamis. Di situlah sebuah nilai akan dapat dirasakan manfaatnya.

Pemanfaatan pappaseng bisa dirasakan dalam bidang pengasuhan anak khususnya proses bimbingan karir anak. Pappaseng dalam konteks ini bisa berupa palette alenu riolo tejjokanu. Konsep ini bisa diinternalisasi dalam bimbingan karir anak yakni pemberian bantuan kepada anak melalui tahap perencanaan dalam hal mengungkap kemampuan anak dan kesesuaiannya dengan jenis pekerjaan. Pappaseng yang bijak ini penting untuk ditantang pada taraf diskusi yang kemudian bisa dioperasionalkan dalam praktik.

Tulisan ini menjadi penting untuk disajikan guna membahas tentang wacana pappaseng (palette alenu riolo tejjokanu) dapat menjadi bagian secara integral dalam proses bimbingan karir anak. Wacana membuka agar pappaseng yang dianggap sakral hanya tidak akan memberi manfaat secara meluas tanpa adanya usaha untuk membuka di ruang diskusi. Kearifan lokal ini akan sangat membantu proses pemberian bimbingan karir anak dalam memandu bagian paling awal.

\section{Bimbingan Karir Anak}

\section{Definisi Bimbingan}

Bimbingan merupakan kata yang dalam bahasa Inggris yaitu "Guidance" dimana kata tersebut berasa dari kata "guide", yang dapat diartikan beberapa yaitu menunjukkan jalan, memimpin, memberikan petunjuk, mengatur, mengarahkan, memberikan nasehat, dan ada juga yang menerjemahkan dengan bantuan atau tuntutan. Bimbingan diartikan secara etimologis berarti bantuan atau tuntutan atau pertolongan yang konteksnya sangat psikologis (Tohirin, 2007:15). 
Menurut Frank Parson, bimbingan adalah bantuan yang diberikan kepada individu untuk memilih, mempersiapkan diri, dan memangku suatu jabatan serta mendapat kemajuan dalam jabatan yang dipilihnya (Anas Salahuddin, 2010:13).

Pendapat mengenai pengertian bimbingan juga dikemukakan oleh Prayitno dan Erman Amti yang mendefinisikan bahwa proses pemberian bantuan yang diberikan kepada seseorang atau beberapa orang, baik anak-anak, remaja maupun dewasa yang bertujuan agar orang yang dibimbing dapat mengembangkan kemampuan dirinya sendiri dan mandiri dengan memanfaatkan kekuatan individu dan sarana yang ada dan dapat dikembangkan berdasarkan norma-norma yang berlaku (Prayitno dan Erman Amti, 2004:99).

Bimbingan merupakan suatu proses berkelanjutan. Berkelanjutan dapat dipahami bahwa kegiatan bimbingan bukan merupakan suatu kegiatan yang dilakukan secara kebetulan, insidensial, sengaja, berencana, kontinu, terarah kepada tujuan (Soraya, 1982:26).

Berdasarkan beberapa definisi yang dikemukan diatas dapat disimpulkan bahwa bimbingan merupakan pemberian bantuan pada individu atau kelompok dengan memberikan pengetahuan tambahan untuk memahami dan mengatasi permasalahan yang dialami oleh individu atau kelompok tersebut, dengan cara terus menerus dan sistematis.

\section{Karir Anak}

Karir adalah perkembangan dan kemajuan dalam kehidupan, pekerjaan, jabatan, dan sebagainya (Kamisa, 1997:284). Usaha anak dalam menjalani proses pertumbuhan dan perkembangannya dalam mencari dan menentukan kemajuan dalam hal pemilihan jenis pekerjaan tentu sesuatu yang tidak mudah. Pemilihan dan penentuan karir tersebut akan baik apabila difasilitasi oleh orang tua baik ayah ataupun ibu.

Professor Edgar H. Schein (dalam Sukardi), menyebutkan bahwa karir adalah suatu pandangan mengenai tingkat kemajuan yang terbatas pada tingginya gaji/upah yang telah membudaya (Dewa, 1989:16). Proses bertumbuh dan berkembangnya anak merupakan suatu tantangan dalam hal memilih dan menentukan bidang pekerjaan yang sesuai dengannya. Pendapatan secara ekonomi 
menjadi bagian yang juga perlu untuk dipertimbangkan dalam proses pemilihan dan penentuan pekerjaan tersebut.

Menurut Donald E mengemukakan bahwa karir adalah sebagai suatu rangkaian pekerjaan, jabatan dan kedudukan yang mengarah pada kehidupan dalam dunia kerja (Dewa, 1989:17). Dunia kerja adalah ruang yang penuh dengan tantangan kepribadian. Tantangan tersebut terkait dengan proses emosional beradaptasi dengan lingkungan. Memilih dan menentukan pekerjaan di dunia kerja yang sesuai dengan minat dan bakat anak akan membantu psikologis anak dalam beradaptasi baik dengan pertemanan dan beban kerja.

Ketiga definisi tentang karir diatas yang telah disampaikan dapat dipahami bahwa karir adalah proses pemilihan dan penentuan status dalam jenjang pekerjaan atau jabatan sebagai sumber nafkah apakah itu berupa mata pencaharian utama ataupun mata pencaharian sampingan. Pemahaman akan pengertian dari karir akan memungkinkan bagi anak dapat memperoleh gambaran tentang berbagai jenis pekerjaan dan jabatan di masyarakat yang dapat dimasukinya. Anak bisa memahami tentang jenis-jenis kemampuan atau keterampilan yang dituntut untuk masing-masing pekerjaan dan jabatan serta latihan yang dapat dilakukan sebagai upaya mengembangkan kemampuan atau keterampilan sesuai dengan bidang karir. Selain itu, dengan memahami karir, anak dapat mengetahui dan dapat menerapkan cara yang perlu di tempuh dalam memilih pekerjaan yang cocok, memperoleh pekerjaan yang telah dipilihnya, dan mendapatkan kemudahan-kemudahan untuk mendapatkan bantuan modal pendukung pencapaiannya.

\section{Bimbingan Karir Anak}

Pemahaman tentang bimbingan dan karir anak diatas dapat dimaknai lagi dengan menggabungkan kata tersebut yaitu bimbingan karir anak dari beberapa pendapat. Menurut Wetik B. mengemukakan bahwa pengertian bimbingan karir adalah program pendidkan yang merupakan layanan terhadap anak agar mampu mengenal dirinya sendiri, mengenal dunia kerja, dapat memutuskan apa yang diharapkan dari pekerjaan dan dapat memutuskan bagaimana bentuk kehidupan yang diharapkannya disamping pekerjaan untuk mencari nafkah. Sementara P. M. 
Hatari juga mengemukakan bahwa bimbingan karir anak membentuk anak dalam proses mengambil keputusan mengenai pekerjaan utama yang mempengaruhi kehidupan di masa depan (Muslim Afandi, 2011:87).

Menurut Ambo Enre Abdullah menjelaskan bahwa bimbingan karir merupakan salah satu jenis bimbingan yang berusaha membantu individu dalam memecahkan masalah karir (pekerjaan) untuk memperoleh penyesuaian diri yang sebaik-baiknya dengan masa depannya. Sementara Winkel mengemukakan bahwa bimbingan karir adalah mempersiapkan diri menghadapi dunia kerja, dalam memilih lapangan pekerjaan atau jabatan (profesi) tertentu serta membekali diri supaya siap memangku jabatan itu dan dalam menyesuaikan diri dengan tuntutantuntutan dari lapangan pekerjaan yang telah dimasuki (Winkel, 1991:124). Bimbingan karir lebih menitik beratkan pada perencanaan kehidupan yang terlebih dahulu haruslah mempertimbngkan potensi diri yang dimilikinya serta lingkungan sekitar agar mereka memperoleh dan memiliki pandangan yagn cukup luas dari pengaruh terhadap peranan positif yang layak dilaksanakannya dalam masyarakat.

Bimbingan karir anak adalah proses perencanaan bagi anak yang memerlukan arahan, bimbingan serta pembelajaran dalam memilih sambil mencari identitas diri anak dalam dunia karir yang sesuai sehingga anak dapat menentukan langkah yang cocok untuknya. Anak yang melalui bimbingan karir mampu bekerja dengan senang hati dan penuh dengan kegembiraan apabila yang dikerjakannya memang sesuai dengan keadaan diri, kemampuan, dan minat yang dimiliki. Karir yang ditentukan bukan dari bimbingan karir dapat dipastikan bahwa anak akan kurng bergairah dalam bekerja, kurang senang dan kurang tekun dalam menyelesaikan pekerjaan.

\section{Tujuan Bimbingan Karir Anak}

Secara umum dapat dipahami bahwa bimbingan karir anak adalah untuk membantu anak memiliki keterampilan dalam mengambil keputusan mengenai karirnya dimasa depan untuk mencapai hal itu diperlukan adanya pemahaman diri 
anak dalam pengamatan lingkungan sekitar yang tepat bagi dirinya sendiri dalam menentukan masa depannya.

Bimo Walgito menjelaskan tujuan bimbingan karir khususnya di lingkungan sekolah dan dalam tulisan ini akan dikaitkan pada lingkup anak dalam keluarga, bahwa untuk membantu anak agar, pertama dapat memahami dan menilai dirinya sendiri, terutama yang berkaitan dengan potensi yang ada dalam dirinya mengenai kemampuan, minat, bakat dan cita-citanya, kedua menyadari dan memahami nilai-nilai yang ada dalam dirinya dan yang ada dalam masyarakat, ketiga mengetahui berbagai jenis pekerjaan yang berhubungan dengan potensi yang ada dalam dirinya, mengetahui jenis-jenis pendidikan dan latihan yang diperlukan bagi suatu bidang tertentu, serta memahami hubungan usaha dirinya yang sekarang dengan masa depannya, keempat menemukan hambatan - hambatan yang memungkinkan timbul yang disebabkan oleh dirinya sendiri dan faktor lingkungan, serta mencari jalan untuk dapat mengatasi hambatan-hambatan tersebut, kelima dapat merencakana masa depannya serta menemukan karir dan kehidupannya yang sesuai (Bimo, 2010:202).

Berdasarkan uraian yang telah dikemukan diatas dapat dipahami bahwa tujuan bimbingan karir anak adalah agar anak memahami potensi yang dimiliki dengan baik dan mengetahui pekerjaan (termasuk beban dan persyaratan) yang harus dipenuhi agar terbentuk suatu kecocokan dengan potensi yang dimiliki anak.

\section{Kearifan Lokal Bugis}

Kearifan lokal adalah gagasan-gagasan setempat (local) yang bersifat bijaksana, penuh kearifan, bernilai baik, yang tertanam dan diikuti oleh anggota masyarakatnya (Agung Setiawan, 2012:203). Dengan kata lain, yang dimaksud dengan kearifan lokal adalah "Pandangan hidup dan ilmu pengetahuan serta berbagai strategi kehidupan yang berwujud aktivitas yang dilakukan oleh masyarakat lokal dalam menjawab berbagai masalah dalam pemenuhan kebutuhan mereka". Olehnya itu, kearifan lokal merupakan usaha atau praktik kebaikan yang bertumbuh dan berkembang dalam suatu kehidupan masyarakat. Praktik kebaikan ini yang terus dijaga dari satu generasi ke generasi lainnya. 
Kearifan lokal atau yang dikenal dengan istilah (local genius/local wisdom) merupakan pengetahuan lokal yang tercipta dari hasil adaptasi suatu komunitas yang berasal dari pengalaman hidup yang dikomunikasikan dari generasi ke generasi. Kearifan lokal dengan demikian merupakan pengetahuan lokal yang digunakan oleh masyarakat lokal untuk bertahan hidup dalam suatu lingkungannya yang menyatu dengan sistem kepercayaan, norma, budaya dan diekspresikan di dalam tradisi dan mitos yang dianut dalam jangka waktu yang lama.

Dalam suku Bugis, kearifan lokal ini bisa dipahami sebagai pappaseng. Pappaseng yang terdiri dari kata dasar paseng berarti nasihat atau petuah yang biasanya berasal dari leluhur kepada anak keturunan, atau dapat juga berasal dari para cendekiawan atau para orang bijaksana kepada masyarakat demi usaha mewujudkan tatanan hidup masyarakat yang lebih mulia. Sebagai sebuah pesan, pappaseng merupakan sebuah jenis pesan yang dianggap sakral sehingga harus dipegang teguh sebagai amanah, bahkan dalam arti tertentu pappaseng merupakan wasiat yang perlu dipatuhi dan senatiasa diindahkan kapan dan di manapun berada.

Awalan pap pada kata paseng membawa makna penegasan bahwa pesanpesan sebagai peringatan yang harus ditaati agar yang menerima wasiat tersebut dengan sungguh-sungguh menjalankan sebagai amanah yang mesti dilaksanakan dengan kesadaran dan tanggung jawab. Pappaseng yang dianggap sakral tersebut membawa konsekuensi bagi penerima yang terkonstruksi apabila dilanggar maka akan mendapatkan peringatan dari Tuhan yang Maha Kuasa (dewata sewwae) berupa kesulitan hidup, malapetaka, dan sebagainya.

Dalam pappaseng terdapat hikmah, sehingga masyarakat Bugis memelihara dan membudayakannya dalam segala aspek kehidupan sehari-hari. Terlebih mengingat bahwa pappaseng dapat diartikan sebagai semacam pedoman hidup yang mulia. Pappaseng yang dapat ditemukan dalam hal motivasi pencapaian atas harapan adalah ungkapan palette alenu riolo tejjokanu. Secara harfiah, pesan ini dapat diartikan bahwa sampailah terlebih dahulu sebelum berangkat. Pesan ini merupakan termasuk ungkapan perintah. Secara operasional 
biasanya dilakukan dengan berdiam diri sejenak sambil memastikan bahwa jasad kita telah berada pada tempat yang hendak didatangi. Pesan ini bisa dipraktikkan pada beragam konteks sosial termasuk dalam hal mencapai target karir.

Palettu alenu riolo tejjokkanu secara bahasa dapat dipahami bahwa palette berarti sampailah, alenu berarti dirimu, riolo berarti sebelumnya, ttejjokanu berarti keberangkatan / bepergian. Paseng ini dapat dipahami sebagai semangat yang mengantar seseorang menjadi seperti yang dipikirkan sebelum memulai perjalanan karir. Perjalanan karir tersebut bisa didesain saat masih anak melalui bantuan dari orang tua. konsep kearifan lokal ini menjadi menarik untuk dipahami dan diterapkan oleh anak dalam hal pemilihan dan penentuan masa depan.

\section{Keterbukaan atas Kearifan Lokal}

Salah satu pappaseng adalah palettu alenu riolo tejjokkanu. Istilah ini bukanlah sesuatu yang hanya dimiliki oleh masyarakat Suku Bugis, namun juga ditemukan pada buku-buku popular yang menjadi referensi kuat dalam bidang pengambangan diri. Buku yang ditulis oleh Stepen R. Covey, yang berjudul The Seven Habit of Highly Effective People. Penulis mengungkapkan bahwa salah satu strategi orang sukses dalam karirnya adalah dengan menerapkan konsep Begin From The End. Konsep ini dapat dipahami bahwa apabila seseorang hendak memulai melakukan sesuatu maka mulailah dari akhir, artinya bahwa membayangkan bahwa kita telah berada atau meraih apa yang menjadi tujuan atau cita-cita. Demikian juga istilah pappaseng ini juga ditemukan pada buku The Secret yang ditulis oleh Rhonda Byrne. Penulis menggunakan istilah the law of attraction. Ungkapan ini dapat dipahami bahwa apa yang dipikirkan akan kembali kepada seseorang tersebut, begitulah cara kerja dari bumi ini. Segala yang dipikirkan maka akan didapatkan kembali, seperti bola yang dipantulkan di atas tanah. Konsep ini menjadi strategi sukses untuk mendapatkan karir. Jenis karir yang diimpikan dihadirkan dalam pikiran, maka semesta ini akan mengabulkan. Dalam buku Quantum Ikhlas yang ditulis oleh Erbe Sentanu menggunakan istilah afirmasi. Afirmasi memiliki pengertian yang sama dengan the law of attraction, gaya tarik menarik bumi bekerja dengan baik. Bagi seseorang yang memikirkan 
sesuatu maka semesta akan memberinya. Ketiga buku ini menjadi argumentasi yang kuat bagi paham berfikir positif.

Berfikir positif tentang karir merupakan awal dari sebuah pencapaian atas karir. Hal ini tentu belum terjadi, artinya bahwa masih dalam pikiran. Islam pun menegaskan pentingnya menjaga pikiran tersebut melalui Hadits nabi bahwa Allah sesuai dengan persangkaan hambanya. Hadits ini menjelaskan kepada manusia bahwa pentingya berprangka baik kepada Allah. Menjaga prasangka baik bahwa Allah akan mengabulkan permintaan karir dari manusia sepanjang memikirkan pencapaian atas karir tersebut.

Penjelasan di atas hendak memaparkan kepada kita bahwa konsep palette alenu riolo tejjokkanu sebenarnya bukanlah sesuatu yang baru sehingga tidak perlu dirahasiakan. Pesan ini bisa jadi merupakan genuine, asli, lahir dari filosofis masyarakat Bugis namun karena merupakan hal yang baik dan memiliki unsur memotivasi maka sebaiknya kearifan lokal ini perlu untuk dikapitalisasi secara terbuka dan menjadi pengetahuan bersama.

Dalam konteks pengasuhan anak, pesan ini menjadi penting untuk diinternalisasi kepada anak oleh orang tua. Pesan ini sebaiknya dibuka dalam ruang diskusi antara orang tua dan anak. Pesan ini sebaiknya disampaikan secara terbuka sehingga orang lain juga berpeluang untuk mengetahui dan menerapkannya. Pesan ini juga penting untuk dibuka agar bisa didiskusikan khususnya bagi akademisi sehingga bisa disajikan sesuai dengan kaidah ilmiah. Empirisitas dari pesan ini akan diuji, apakah hanya sebatas pengetahuan empiris atau ilmiah yang teruji.

\section{Wacana Penerapan Bimbingan Karir Anak Berbasis Kearifan Lokal Bugis}

Menurut Abd. Rahim Yunus menegaskan bahwa terdapat empat unsur yang membentuk kearifan lokal yakni pertama, manusia, kedua, gagasan yang bernilai baik, ketiga, kebenaran yang telah mentradisi, dan keempat, diakui oleh masyarakat (Abd. Rahim Yunus, 2015:1). Dengan menggunakan keempat unsur tersebut dalam memahami wacana penerapan palettu alenu riolo tejjokkanu pada 
lingkup pengasuhan anak, maka kita akan memahami penting mewacanakan pesan ini ke wilayah terbuka.

Manusia hidup bertumbuh dan berkembang sesuai dengan konteks. Konteks dapat dipahami sebagai ruang dan waktu. Saat ini manusia berada pada ruang dan waktu dimana masyarakat dituntuk untuk mengedepankan kolaborasi dan kompetensi. Masa dimana manusia satu dengan lainnya diniscayakan untuk merangkul bersama mencapai target bersama. Setiap momen didiskusikan dan dieksekusi secara bersama. Setiap kesempatan menjadi bagian dari persaingan sehat bagi lainnya. Demikianlah peluang harus dimanfaatkan secara terbuka dan bersama, sehingga masalah bisa menjadi beban bersama.

Karir anak yang dirancang sejak dini adalah kesempatan emas bagi orang tua. Orang tua sebaiknya bisa memanfaatkan kesempatan untuk memastikan anak hidup sesuai dengan kebutuhan konteks saat ini. Perjalanan karir anak haruslah difasilitasi oleh orang tua baik dalam memahamkan kemampuan anak dan jenis dan tantangan pekerjaan. Sebagai masyarakat Bugis, bimbingan karir ini bisa dilaksanakan dengan mengedepankan filosofis palette alenu riolo tejjokanu. Paseng bijak ini dapat mengantarkan imajinasi anak berada pada tantangan karir yang akan dihadapi. Imajinasi bermakna bahwa anak mampu membayangkan bahkan menghadirkan dirinya sebagai pemilik atau pekerja pada jenis pekerjaan. Imajinasi ini adalah kekuatan dan semangat anak agar tetap termotivasi mendapatkannya. Bimbingan karir dalam hal ini bisa dilakukan melalui merelaksasi anak dengan berimajinasi berada pada momen tertentu.

Paseng tersebut selain sebagai imajinasi anak, juga akan mengantarkan anak pada gagasan yang bernilai baik. Gagasan ini adalah penalaran anak, artinya bahwa anak akan ditantang untuk memikirkan ide dan konsep secara tersistematis. Wilayah gagasan ini adalah kognitif artinya adanya kesadaran anak untuk melihat secara nyata imajinasi tersebut. Bimbingan karir dalam hal ini bisa dilakukan dengan membuat drama gagasan tersebut.

Palette alenu riolo tejjokanu adalah wasiat yang dilisankan oleh orang tua Bugis secara turun temurun dan secara empiris telah terbukti terjadi. Olehnya itu pesan ini adalah kebenaran yang telah mentradisi. Paham ini telah terinternalisasi 
dalam lingkup keturunan meskipun secara tertutup. Empirisme ini bisa diinternalisasi dalam diri anak. Bimbingan karir dalam hal ini yang bisa dilakukan adalah dengan memetakan kemampuan anak sesuai dengan pengalaman anak. Pengalaman keseharian anak tersebut secara sederhana bisa dijadikan sebagai panduan dalam memetakan minat dan bakat anak sambil menyesuaikan dengan jenis pekerjaan. Bimbingan karir anak dalam hal ini bisa dilaksanakan melalui check list behavior anak dan diskusi terbuka mengenai kesempatan dan peluang masa depan.

Palette alenu riolo tejjokanu yang secara empiris tersebut terbukti pada akhirnya diakui oleh masyarakat. Diakui berarti bahwa ada dan digunakan terus menerus. Pesan ini terinternalisasi di tengah masyarakat dan menjadi praktik dalam kehidupan keseharian. Unsur ini meniscayakan pesan Palette alenu riolo tejjokanu untuk dapat dikanalisasi dalam bimbingan karir anak, menjadi bagian penting dari materi lainnya.

\section{SIMPULAN}

Palette alenu riolo tejjokanu secara empiris telah terbukti diyakini dan dibenarkan oleh masyarakat Bugis. Keyakinan yang berdasar pada empirisme tersebut perlu untuk dibawa ke ruang terbuka agar bisa menjadi bagian dari kebermanfaatan dalam bidang pengasuhan anak melalui bimbingan karir anak. Kebenaran yang berbasis pada empirisme tersebut juga penting untuk dibuktikan dengan kaidah ilmiah oleh akademisi. Oleh karena itu, membuka di ruang publik untuk didiskusikan akan lebih membawa nilai kebermanfaatan pada paseng Bugis ini khususnya dalam bidang pengasuhan anak. Pada akhirnya akan digunakan oleh professional yang bergerak pada bidang bimbingan karir anak.

Palette alenu riolo tejjokanu bisa diterapkan pada bimbingan karir anak melalui imajinasi karir anak, drama karir, chech list behavior anak, dan diskusi terbuka anak. 


\section{DAFTAR PUSTAKA}

Abdullah, A. E. 1984. Bimbingan Karir dan Orang Tua. Jakarta : BP3K

Afandi, M. 2011. "Tipe Keribadian dan Model Lingkungan dalam Perspektif Bimbingan Karir John Holland", Jurnal Sosial Budaya, Vol. 8, No. 01 (Januari-Juni, 2011).

Djumhur, M. S., 1982. Bimbingan dan Penyuluhan di Sekolah. Bandung: Ilmu.

Kamisa, 1997. Kamus Lengkap Bahasa Indonesia. Surabaya: Kartika

P.M. Hatari, 1981. Kearah Pengertian Bimbingan Karir dengan Pendekatan Developmental. Jakarta: BP3K

Prayitno dan Erman Amti, 2004. Dasar-Dasar Bimbingan Konseling. Jakarta: Renika Cipta.

Salahuddin, A. 2010. Bimbingan \& Konseling. Bandung: CV Pustaka Setia.

Setiawan, A. 2012. Budaya Lokal Dalam Perspektif Agama: Legitimasi Hukum Adat ('Urf) Dalam Islam. Jurnal esensia Vol. XIII No. 2 Juli 2012.

Sukardi, D. K., 1989. Bimbingan Karir di Sekolah-sekolah. Jakarta: Ghalia Indonesia.

Tohirin, 2007. Bimbingan dan Konseling di Sekolah dan Madrasah. Jakarta: PT. Raja Grafindo Persada.

Yunus, A. R. 2015. Nilai-Nilai Islam Dalam Budaya dan Kearifan Lokal (Konteks Budaya Bugis). Jurnal Rihlah, Vol. II No. 1 Mei 2015.

Walgito, B. 2010. Bimbingan + Konseling; Studi \& Karir. Yogyakarta: CV. Andi Offset.

Wetik B, 1981. Pengertian Dasar dan Tujuan Bimbingan Karir. Jakarta: BP3K.

Winkel, 1991. Bimbingan dan Konseling di Institusi Pendidikan. Jakarta: PT. Gramedia. 